\title{
New Technology for Production of Leather for Gloves and Fancy Goods
}

\author{
Aigul Kudabayeva ${ }^{1}$, Bekzhan Abzalbekuly ${ }^{1}$, Urana Dandar ${ }^{2}$, Ersin Onem² ${ }^{2}$, Behzat Oral Bitlisli² \\ ${ }^{1}$ M. Kh. Dulaty Taraz State University, Tolei bi str. 60, 080000 Taraz, Kazakhstan \\ ${ }^{2}$ Department of Leather Engineering, Faculty of Engineering, Ege University, 35100 Bornova-Izmir, Turkey
}

Corresponding Author: Ersin Onem, ersin.onem@ege.edu.tr

\begin{abstract}
The results of the development of chromium saving method for obtaining of glove-haberdashery leather, allowing to improve the quality of leather and to provide the ecological safety of production, were presented in the paper. Leather tanning with ecologically harmless tannages under proper parameters and consumption of chemical materials was carried out in semi-production conditions. The improvement of glove-haberdashery leather quality was achieved by partial replacement of chromium by complex compounds, containing titanium and aluminum. Physical and mechanical properties of glove-haberdashery ecologically harmless leathers corresponded the standard norms and can be recommended for production of men's and women's gloves.
\end{abstract}

\author{
ARTICLE HISTORY \\ Received: 25.11.2019 \\ Accepted: 03.12.2020

\section{KEYWORDS} \\ Tanning, eco-friendly \\ technology, environmental \\ safety, glove-haberdashery \\ leather, titanium, aluminum.
}

\section{INTRODUCTION}

The most rational technological decision, allowing improvement of ready leather quality and providing ecological safety of leather industry, is the use of ecologically harmless chemical materials. Application of such chemical materials allows to intensify technological processes and to apply leather raw material rationally.

Tanning is one of the main leather processing including sufficient changes of dermis structure and determining the leather quality and economic component of production to a great extent. In this process, ecologically harmless complex compounds including metals like titanium and aluminum are wide spread. Their application is based on their ability to interact with various active groups of collagen in order to obtain tanned and filled skin tissue. In tanning process ecologically harmless complex mineral hardeners react with collagen mainly due to the same functional groups and form the links, which are inherent to their components [1-6]. It is especially valuable in the production of glove-haberdashery leather as soon as more strict requirements are made to thin glove leather. Their appearance and color must satisfy consumer. Glove-haberdashery leather must be soft, plastic, dimensionally stable and strong tensile.

At present time great number of tanning methods with application of two, three or more tanning components have been worked out. Perspective kinds of mineral tanning methods are: chromium-titanium tanning, which complexes are strong and stable, and give dimensional stability and high occupancy to the leather [7-9]; chromium-aluminum tanning, allowing obtaining of soft leather with delicate front layer, which is easily colored and possesses some properties of chromium leather [10-12]. The use of chromium-aluminum complex is reducing the content of chromium in wastewaters and simplifies the further processing of leather [13].

Titanium and aluminum agents are used in leather production for the replacement of chromium in different ecological researches; on the other hand this study focuses the production of leather for gloves and fancy goods, and related the suitable implementation and results with the use of these complexes.

To cite this article: Kudabayeva A, Abzalbekuly B, Dandar U, Onem E, Bitlisli BO. 2020. New Technology for Production of Leather for Gloves and Fancy Goods. Tekstil ve Konfeksiyon, 30(4), 270-275. 


\section{EXPERIMENTAL DETAILS}

\subsection{Material and production experiments}

In order to obtain glove-haberdashery leather from Kazakh domestic rabbit pelts searching experiments on domestic rabbit pelt sample compiled by halves method have been carried out.

Moistening and soaking-liming processes have been conducted according to previously defined optimal parameters - according to the standard method of production of glove-haberdashery leather. It was stated that aluminumchromium ratio in tanning is to be $\mathrm{Cr}_{2} \mathrm{O}_{3}: \mathrm{Al}_{2} \mathrm{O}_{3}=1: 1$, and for titanium-chromium ratio is to be $\mathrm{Cr}_{2} \mathrm{O}_{3}: \mathrm{TiO}_{2}=3: 1$. Such conditions provide obtaining of soft, filled glovehaberdashery leather with improved appearance.

In order to work out optimal parameters of chromiumtitanium and chromium-aluminum tanning on the base of the experiment planning theory these processes have been optimized.

The temperature of collagen welding is used as indicator of tanning degree of skin [14-17]. Therefore, the temperature of welding of semi finished products has been estimated during tanning process. Experimental results allowed determining optimal parameters of tanning, at which necessary temperature of welding at minimal expense of tanning reagents was reached. Data on welding temperature, $\mathrm{pH}$ and concentration of tanning reagents in semi finished products show that maximal effect is reached at the following consumption of reagents in terms of metal oxides in chromium-titanium tanning: $\mathrm{Cr}_{2} \mathrm{O}_{3}-1.0 \%$ from the total mass of raw hide, $\mathrm{TiO}_{2}-0.6 \%$; in chromium-aluminum tanning: $\mathrm{Cr}_{2} \mathrm{O}_{3}-1.0 \%, \mathrm{Al}_{2} \mathrm{O}_{3}-0.8 \%$ at tanning duration -3 hours [18].

\subsection{Calculations and coefficient of the process}

Ecologically harmless chromium-aluminum and chromiumtitanium complex hardeners are characterized by good tanning activity, and respectively by high filling and plasticizing effects which determine the feasibility of joint use of these hardeners aimed to the development of three component complex chromium-aluminum-titanium hardener. The scheme of chromium-aluminum-titanium tanning for obtaining of glove-haberdashery leather is analogous to chromium-titanium and chromium-aluminum tanning.

The chromium consumption $\left(X_{1}\right)$, aluminum consumption $\left(X_{2}\right)$ and titanium consumption $\left(X_{3}\right)$ have been chosen as the factors influencing the efficiency of tanning. As optimization criteria welding temperature of semi products samples has been adopted as $Y_{1}, Y_{2}$ content of aluminum, $Y_{3}$ - content of titanium and $Y_{4}$ - content of chromium.

The intervals and level of factor variation have been selected taking into account the results of searching experiment. Symbols and variation levels of factors are represented in Table 1.

Table 1. Main characteristics of experiment

\begin{tabular}{|c|c|c|c|c|}
\hline Factor name & Parameters & $\mathrm{X}_{1}$ & $\mathrm{X}_{2}$ & $X_{3}$ \\
\hline \multirow{2}{*}{$\begin{array}{l}\mathrm{X}_{1} \text {-consumption of } \\
\text { chromium hardener } \\
\left(\mathrm{Cr}_{2} \mathrm{O}_{3}\right) \% \text { from } \\
\text { total mass of raw } \\
\text { hide }\end{array}$} & $\begin{array}{l}\text { Top level of } \\
\text { factor }(-1)\end{array}$ & 1.2 & 1.2 & 0.9 \\
\hline & $\begin{array}{l}\text { Lower level of } \\
\text { factor }\end{array}$ & 0.6 & 0.9 & 0.3 \\
\hline \multirow{2}{*}{$\begin{array}{l}\mathrm{X}_{2} \text { - consumption } \\
\text { of potassium alum } \\
\left(\mathrm{Al}_{2} \mathrm{O}_{3}\right) \% \text { from } \\
\text { total mass of raw } \\
\text { hide }\end{array}$} & $\begin{array}{l}\text { Basic level of } \\
\text { factor }(+1)\end{array}$ & 0.9 & 1.05 & 0.6 \\
\hline & $\begin{array}{l}\text { Variation levels } \\
\text { of factor }(0)\end{array}$ & 0.3 & 0.15 & 0.3 \\
\hline $\begin{array}{l}\mathrm{X}_{3} \text { - sulfate } \\
\text { titanilate of } \\
\text { ammonia } \mathrm{TiO}_{2} \% \\
\text { from total mass of } \\
\text { raw hide }\end{array}$ & Ratio & 3 & 7 & 2 \\
\hline
\end{tabular}

Coefficients of regression equations have been calculated and evaluation of their significance has been carried out with a help of Fisher's criterion. The equations obtained adequately characterize the dependence between welding temperature and content of $\mathrm{Al}_{2} \mathrm{O}_{3}, \mathrm{TiO}_{2}$ and $\mathrm{Cr}_{2} \mathrm{O}_{3}$ in the samples of produced leather.

\subsection{Modelling of the process}

The hypothesis of adequate model has been verified by Fisher's criterion (F-criterion) [19]. Conditionality is sustained, therefore the second order mathematical model obtained can be regarded adequate with a probability of $95 \%$, the calculated Fisher coefficient is 2,63 for $Y_{1}, 2,08$ for $Y_{2}, 0,88$ for $Y_{3}, 1,04$ for $Y_{4}$.

As a result of mathematical processing the following regression equations have been obtained:

$$
\begin{aligned}
& Y_{1}\left(T_{c B}\right)=107,25+8,23 * X_{1}+ \\
& +2,17 * X_{2}+4,85 * X_{3}+ \\
& +0,63 * X_{1} * X_{2}+1,38 * X_{1} X_{3}- \\
& -0,63 * X_{2} X_{3}-3,27 * X_{1}^{2}+ \\
& +0,43 * X_{2}^{2}-2,21 * X_{3}^{2} \\
& Y_{2}\left(\mathrm{Al}_{2} \mathrm{O}_{3}\right)=2,03-0,02 * X_{1}+ \\
& +0,23 * X_{2}+0,14 * X_{3}+ \\
& +5,55 * X_{1} * X_{2}-0,05 * X_{1} X_{3}+ \\
& +5,55 * X_{2} X_{3}+0,31 X_{1}^{2}+ \\
& +0,281 * X_{2}^{2}+0,24 * X_{3}^{2} ; \\
& Y_{3}\left(T i O_{2}\right)=1,30-0,03 * X_{1}+ \\
& +0,05 * X_{2}+0,23 * X_{3}+ \\
& +0,03 * X_{1} X_{2}+0,03 * X_{1} X_{3}+ \\
& +0,03 * X_{2} X_{3}+0,02 * X_{1}^{2}- \\
& -0,01 * X_{2}^{2}-0,02 * X_{3}^{2} ;
\end{aligned}
$$




$$
\begin{aligned}
& Y_{4}\left(\mathrm{Cr}_{2} \mathrm{O}_{3}\right)=3,17+0,43 * X_{1}+ \\
& +0,06 * X_{2}-0,24 * X_{3}- \\
& -0,1 * X_{1} * X_{2}-5,6 * X_{1} * X_{3}+ \\
& +5,55 * X_{2} * X_{3}-0,15 * X_{1}^{2}- \\
& -0,08 * X_{2}^{2}-0,18 * X_{3}^{2}
\end{aligned}
$$

Based on the analysis of regression equations we can make the following conclusions: the positive signs "+" at $X_{1} X_{2}$ and $X_{1} X_{3}$ indicate that in joint tanning by aluminum $\left(X_{2}\right)$ titanium $\left(X_{3}\right)$ and chromium $\left(X_{I}\right)$ compounds (the last acts as stabilizer) these metals are complementary, but do not displace each other. Pair interactions in equation (1) chromium-aluminum and chromium-titanium show that they promote raising of welding temperature of experimental samples of semi-finished products, and aluminum-titanium on the contrary lowers the temperature (sign "-"” at $X_{1} X_{2}$ ).

The analysis of equation (2) proves that joining of chromium and aluminum (positive sign “+” at $X_{1} X_{2}$ ) promotes the formation of stable complexes and fastens the links of aluminum with collagen.

Adsorption of aluminum and titanium from the solution depends largely on the chromium consumption. Sign "-" at $X_{1}$ in equations 2, 3 denote that decrease of chromium content leads to the increase of waste aluminum and titanium content in the solution. This is proved by pair contribution (sign "+" at $X_{1} X_{2}$ ).

In equation (3) pair interaction of factors (sign "+" at $X_{1} X_{2}$, $X_{1} X_{3}$, and $X_{2} X_{3}$ ) indicate the formation of stable complexes increasing the links with collagen. Negative signs at $X_{2}^{2}$ and $X_{3}^{2}$ indicate that decrease of aluminum and titanium consumption slow down penetration into the dermis structure.

Equation (4) confirms that decrease of expense of aluminum compounds in combination with chromium compounds (sign "-" at $X_{1} X_{2}$ and $X_{1} X_{3}$ ) will influence the decrease of linking of these compounds with collagen. Sign "-" at $X_{3}$ indicates that decrease of titanium expense worsens its absorption may be because of strong hydrolysis, therefore it is necessary to increase the quantity of chromium and aluminum (sign "+" at $X_{1}$ and $X_{2}$ ), rendering stabilization effect on titanium.

\subsection{Characterization techniques applied on leather}

Chemical and physical analyses were carried out as defined in GOST 15092-80 [20]. Analyses of thickness according to TS EN ISO 2589 [21], tensile strength and percentage extension tests to TS EN ISO 3376 [22], pH to TS EN ISO 4045 [23], moisture content to TS EN ISO 4684 [24], chrome oxide TS EN ISO 5398-1 [25] and matter soluble content to TS EN ISO 4048 [26] were performed.

\section{RESULTS AND DISCUSSION}

As a result of the experiment optimal values of parameters of chromium-titanium tanning have been estimated and maximal tanning effect have been stated at following parameters and consumption of chemical materials: consumption of potassium alum, counting on $\left(\mathrm{Al}_{2} \mathrm{O}_{3}\right.$; basicity $40 \%$ ) is $0.8 \%$ from the mass of raw hide; consumption of sulfate titanilate of ammonia, counting on $\mathrm{TiO}_{2}$ (basicity $60 \%$ ) is $0.6 \%$ from the raw hide mass; consumption of chromium tanner, counting on $\left(\mathrm{Cr}_{2} \mathrm{O}_{3}\right.$; basicity $\left.38 \%\right)$ is $0.9 \%$ from the raw hide mass; sodium carbonate $-1.0 \%$ from the raw hide mass; liquid ratio 0.4 ; tanning duration -3 hours; initial temperature of tanning $-21^{\circ} \mathrm{C}$.

Application of chromium-aluminum-titanium complex leads to lowing of chromium compounds expense to $44 \%$, that is only $0.9 \%$ of chromium salts instead of $1.6 \%$ of chromium oxide used according to standard method of tanning of glove- haberdashery leather that provide improvement of wastewater conditions. At the same time high thermal stability of glove- haberdashery leather is reached.

Water-soaking, liming, pre tanning and tannin processes according to elaborated technologies of glove-haberdashery leather production of chromium-titanium, chromiumaluminum and chromium-aluminum-titanium tanning at proper parameters of chemical reagent consumption, and dying-fat liquoring processes according standard methods of glove-haberdashery leather production.

As a result of experiment light colored samples have been obtained which had following organoleptic properties: good density, fullness and softness. At the same time the distinctive grain pattern, which uniformly located over the entire surface single points, have been retained.

Physical and mechanical properties are the main characteristics of leather quality (strength, longevity, etc.). They are due to the ability of leather to resist to various types of loading, and its deformation capacity as well.

Samples of semi finished products obtained by chromiumtitanium, chromium-aluminum and chromium-aluminumtitanium tanning have been exposed to physical-mechanical tests. The results of physical-mechanical parameters are represented in Table 2 .

Chromium-titanium tanned leather is characterized by good density, fullness, dimensional stability and high strength index.

Chromium-aluminum tanned leather is characterized by softness, plasticity and soft front surface.

Chromium-aluminum-titanium tanned leather is characterized by softness, dimensional stability, good density and fullness, and high strength index and elasticplastic properties as well. 
Table 2. Results of physical-mechanical tests of glovehaberdashery leather obtained by chromium-titanium (CT), chromium-aluminum (CA) and chromiumaluminum-titanium (CAT) tanning

\begin{tabular}{|c|c|c|c|c|}
\hline \multirow{2}{*}{\multicolumn{2}{|c|}{$\begin{array}{l}\text { The name of leather } \\
\text { Tanning method }\end{array}$}} & \multicolumn{3}{|c|}{$\begin{array}{l}\text { Glove- haberdashery } \\
\text { leather }\end{array}$} \\
\hline & & CT & $\mathrm{CA}$ & CAT \\
\hline \multicolumn{2}{|l|}{ Thickness, mm } & \multicolumn{3}{|c|}{2} \\
\hline \multicolumn{2}{|c|}{ Cross-sectional area } & \multicolumn{3}{|c|}{2} \\
\hline \multirow{2}{*}{ Loading, $\mathrm{N}$} & $\begin{array}{l}\text { Cracking of } \\
\text { front layer }\end{array}$ & 17.2 & 14.8 & 17.6 \\
\hline & $\begin{array}{l}\text { Breaking of the } \\
\text { sample }\end{array}$ & 18.8 & 16.2 & 19.2 \\
\hline \multicolumn{2}{|c|}{ Conditional elastic modulus, $\mathrm{N} / \mathrm{m}^{2}$} & 4.9 & 3.8 & 4.1 \\
\hline \multicolumn{2}{|c|}{ Rigidity, N } & 9.8 & 7.6 & 8.2 \\
\hline \multirow{2}{*}{$\begin{array}{l}\text { Breaking point, } \\
\mathrm{MPa}\end{array}$} & $\begin{array}{l}\text { Cracking of } \\
\text { front layer }\end{array}$ & 8.6 & 7.4 & 8.8 \\
\hline & Under tension & 9.4 & 8.1 & 9.6 \\
\hline \multicolumn{2}{|c|}{ Coefficient of uniformity } & \multicolumn{3}{|c|}{8} \\
\hline \multirow{5}{*}{ Elongation, $\mathrm{mm}$} & $\begin{array}{l}\text { Under tension } \\
\text { of } 9.8 \mathrm{Mpa}\end{array}$ & 10 & 13 & 12 \\
\hline & $\begin{array}{l}\text { Cracking of } \\
\text { front layer }\end{array}$ & 22 & 26 & 25 \\
\hline & $\begin{array}{l}\text { Breaking of the } \\
\text { sample }\end{array}$ & 25 & 30 & 29 \\
\hline & Elastic & 10 & 12 & 12 \\
\hline & Residual & 15 & 19 & 17 \\
\hline \multirow{5}{*}{$\begin{array}{l}\text { Relative } \\
\text { elongation, } \%\end{array}$} & $\begin{array}{l}\text { Under tension } \\
\text { of } 9.8 \mathrm{Mpa}\end{array}$ & 20 & 26 & 24 \\
\hline & $\begin{array}{l}\text { Cracking of } \\
\text { front layer }\end{array}$ & 44 & 52 & 50 \\
\hline & $\begin{array}{l}\text { Breaking of the } \\
\text { sample }\end{array}$ & 50 & 60 & 58 \\
\hline & Elastic & 20 & 24 & 24 \\
\hline & Residual & 30 & 36 & 34 \\
\hline
\end{tabular}

Data represented are arithmetic mean of three measurements

Experiments allowed to adjust that physical-mechanical properties of glove- haberdashery leather correspond standard characteristics for glove-haberdashery leather and have following differences: leather of chromium-titanium tanning exceeds leather of chromium tanning in strength parameter; leather of chromium-aluminum tanning - in elongation parameter; leather of chromium-aluminumtitanium tanning exceeds on strength and elastic-plastic parameters.

So, optimal mass ratio $\mathrm{Cr}_{2} \mathrm{O}_{3}: \mathrm{Al}_{2} \mathrm{O}_{3}: \mathrm{TiO}_{2}=0.9: 0.8: 0.6$ was determined, at which the highest welding temperature, even leather filling and high elastic-plastic parameters had been reached [27].

Chemical composition and mechanical properties of glovehaberdashery leather of chromium-titanium, chromium- aluminum and chromium-aluminum-titanium tanning are compiled in Table 3.

Table 3. Chemical composition and mechanical parameters of glove-haberdashery leather of chromium-titanium, chromium-aluminum and chromium-aluminum-titanium tanning

\begin{tabular}{|c|c|c|c|c|}
\hline \multirow[b]{2}{*}{ Parameter } & \multirow{2}{*}{$\begin{array}{c}\text { State } \\
\text { Standard } \\
15092-80\end{array}$} & \multicolumn{3}{|c|}{ Experimental } \\
\hline & & $\mathrm{CT}$ & $\mathrm{CA}$ & CAT \\
\hline Moisture, \% & $10-16$ & 14.6 & 14.6 & 14.6 \\
\hline $\begin{array}{l}\text { Compounds, extracted } \\
\text { by organic solvents, } \%\end{array}$ & $12-20$ & 12.4 & 12.4 & 12.4 \\
\hline Chromium oxide, $\%$ & 3 & 3,2 & 3,2 & 3 \\
\hline Titanium oxide, $\%$ & 0 & 1.6 & 0 & 1.4 \\
\hline Aluminum oxide, $\%$ & 0 & 0 & 2,4 & 2 \\
\hline $\begin{array}{l}\text { Grease (for all kinds of } \\
\text { skin, except pigskin) }\end{array}$ & $4-12$ & 6 & 6 & 5,8 \\
\hline $\mathrm{pH}$ of water extract & $4-6$ & 4.6 & 4.6 & 4.6 \\
\hline $\begin{array}{l}\text { Ultimate strength of } \\
\text { elongation, } \mathrm{MPa} \text { (for } \\
\text { all kinds of skin, except } \\
\text { pigskin) }\end{array}$ & $8-10$ & 9.4 & 8.1 & 9.6 \\
\hline $\begin{array}{l}\text { Ultimate strength of } \\
\text { elongation of front } \\
\text { layer, } \mathrm{MPa} \text {, no less } \\
\text { than }\end{array}$ & $8-10$ & 8.6 & 7.4 & 8.8 \\
\hline $\begin{array}{l}\text { Elongation at breaking } \\
\text { point, } \% \text {, no less than }\end{array}$ & $40-45$ & 50 & 60 & 58 \\
\hline
\end{tabular}

The most common method of estimation of strength properties of leather is the test on mono axial tension [2831].

The semi-products samples of chromium, chromiumtitanium, chromium-aluminum and chromium-aluminumtitanium tanning have been exposed to the mono axial tension test. As it can be seen from Figure 4, elongation curves for semi-products obtained from rabbit pelts by various tanning methods are just like the curves for soft leather, namely these curves are convex to the elongation axis that is quite important for glove-haberdashery leather.

For glove-haberdashery leather the elongation index is of great importance, because during exploitation gloves meet permanent elongation causing deformation of their initial form, and regeneration is possible only in the presence of elastic properties.

At the beginning of exploitation of gloves leather must have certain level of permanent deformation for easy and convenient removal and donning of gloves.

If the curves are conditionally divided into three intervals: I- permanent elongation, II-elastic elongation, III-plastic elongation and destruction phase, then, as it can be seen from Figure 1 elongation curves of semi-products of chromium, chromium-aluminum and chromium-aluminum- 
titanium tanning have a large percent of permanent elongation - 1- area of smooth beginning of the curves.

The existing dependence between increase of loading and elastic elongation show that increase of elastic elongation II- area of the curves, convex to the elongation axis - is behind the loading increase, it testifies high elastic properties of given samples of semi-products of chromium and chromium-aluminum-titanium tanning (Figure 1).

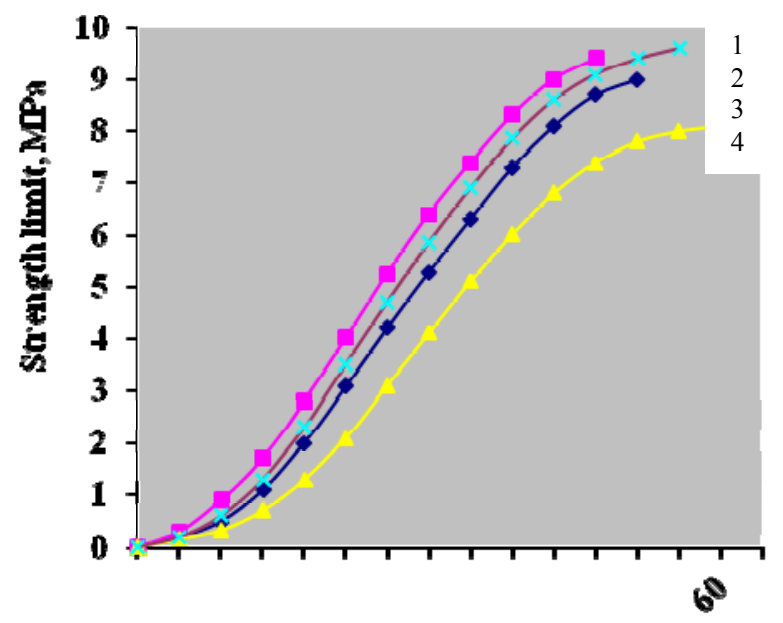

Relative elongation, $\%$

Figure 1. Curves of elongation of semi-product samples obtained by various tanning methods (1- chromium-titanium, 2 chromium-aluminum-titanium, 3- chromium, 4chromium-aluminum)

Maximum curvature of the curve of semi-product sample obtained by chromium-aluminum tanning is probably due to the particles of aluminum and chromium compounds absorbed on the surface of structural elements, which facilitate their orientation (irreversible movements), that decreases leather facility for elastic elongation; and thus enhances its plastic properties [32]. However, excessively high plastic properties are not reliable for glove-haberdashery leather because they contribute weak dimensional stability. The curvature of the curve of semi-product sample obtained by chromium-aluminum tanning indicates that leather processed by this tanning method will have low strength.

The curve of semi-product sample obtained by chromiumtitanium tanning, the growth of loading in sector $I$ is quicker than the growth of relative elongation, apparently due to the particles of titanium tanner absorbed on the surface of structural elements, lowing their orientation ability and creating rigid frame, enforcing fibrous structure of dermis that leads to the growth of strength limit and to the decrease of elongation of semi-products. More rectified course of the curve of semi-product obtained by chromiumtitanium tanning indicates insufficient softness which is quite necessary for glove-haberdashery leather. It has also been confirmed by relatively high elastic module.

The comparison of courses of deformation curves show that semi-finished products obtained by chromium-aluminumtitanium tanning are preferable, because in terms of elongation they are not interior to chromium-aluminum tanned semi-finished products, and at the same time have better strength parameters than semi-finished chromiumtitanium tanned semi-finished products. The best elasticplastic properties of these samples are due to better flexibility of structural elements of dermis, which have the most adequate response to the load, causing the deformation. To great extent in is caused by joint application of separate types of mineral tanners - $\mathrm{Cr}$, $\mathrm{Al}$ and $\mathrm{Ti}$ as three component complex mineral tanner.

Glove-haberdashery leather samples have been produced by applying the results of experiments based on the developed technology. Organoleptic qualitative evaluation of glovehaberdashery leather which confirmed following properties; complete tanning, good appearance, softness, even surface and color, smooth and well processed reverse side, have been carried out (Figure 2).
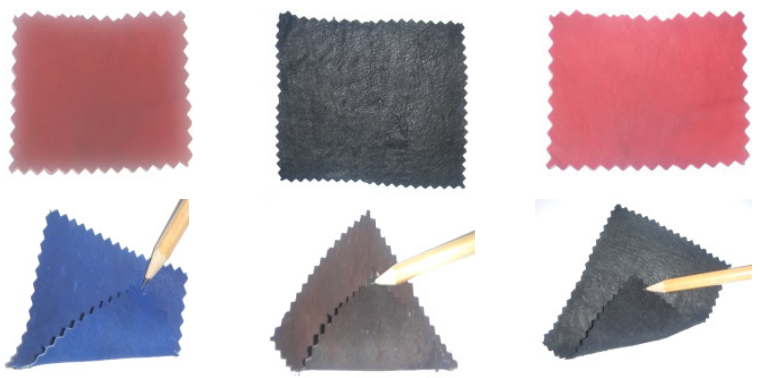

Figure 2. Experimental samples of glove-haberdashery leather produced from domestic rabbit pelts (face and reverse sides)

Men's gloves have been made from glove-haberdashery leather obtained (Figure 3). Further works are related to improvement of constructive-technological solution of this model and design of men's and woman's gloves.
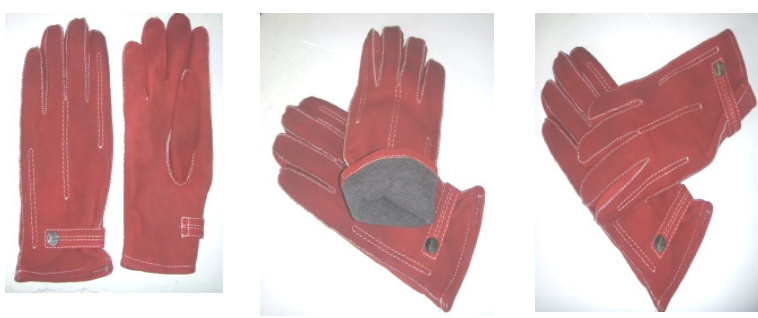

Figure 3. Appearance of men's gloves

\section{CONCLUSION}

During production of the glove-haberdashery leathers with proper correction of process parameters, necessary ecologically harmless materials have been chosen and their expense has been taken into account, properties of the material have been clarified. Investigation of physicalmechanical properties of glove-haberdashery leather has shown that they provided the standard requirements. According to our study, men's gloves have been successfully manufactured with satisfactory results from ecologically harmless recipe designed for glovehaberdashery leathers by chromium saving methods. 


\section{REFERENCES}

1. Zengin ACA, Crudu M, Maier SS, Deselnicu D, Albu L, Gulumser G, Bitlisli BO, Basaran B, Mutlu MM. 2012. Eco-leather: Chromium-free leather production using titanium, oligomeric melamine-formaldehyde resin, and resorcinol tanning agents and the properties of the resulting leathers. Ekoloji, 21, 17-25.

2. Madiev UK. 1987. Mineral'noe dublenie v proizvodstve kozh. Moskva: Legprombytizdat, 120p

3. Peng BY, Shi B, Ding KY, Fan HJ, Shelly DC. 2007. Novel titanium (IV) tanning for leathers with superior hydrothermal stability - III. Study of factors affecting titanium tanning and an eco-friendly titanium tanning method. Journal of the American Leather Chemists Association, 102, 297-305.

4. Gerasimova LG, Shchukina ES, Ohrimenko RF, Maslova MV. 2013 On the behavior of titanium(IV) sulfate in aqueous media used in leather tanning. Russian Journal of Applied Chemistry, 86, 453-457.

5. Mutlu MM, Crudu M, Maier SS, Deselnicu D, Albu L, Gulumser G, Bitlisli BO, Basaran B, Tosun CC, Zengin ACA. 2014. Eco-leather: Properties of chromium-free leathers produced with titanium tanning materials obtained from the wastes of the metal industry. Ekoloji, 23, 83-90

6. Rosu L, Varganici CD, Crudu AM, Rosu D. 2018. Influence of different tanning agents on bovine leather thermal degradation. Journal of Thermal Analysis and Calorimetry, 134, 583-594.

7. 7. Kozyreva NV, Bajandin VV, Klenovskaja NV. 1990. Fizikomehanicheskie svojstva kozh dlja verha obuvi titanhromovogo metoda dublenija. Kozhevenno-Obuvnaja Promyshlennost, 4, 58-60.

8. Crudu M, Deselnicu V, Deselnicu DC, Albu L. 2014. Valorization of titanium metal wastes as tanning agent used in leather industry. Waste Management, 34, 1806-1814.

9. Wang KJ, Chen YN, Dan NH, Li F, Dan WH. 2018. Chrome-less tanning - a non-pickling process based on $\mathrm{Zr}$-Al-Ti complex tanning agent. Journal of the Society of Leather Technologists and Chemists, $102,1-6$.

10. Zissel A, Schmidt G, Magerkurth B. 1980. Der Erstz des Chroms durch aluminium und andere Gerbstoffe im Hinbiick uf Leder character Gerbsoffbindund. Leder, 2, 17-24.

11. Han W, Zhou CF, Zhang WH, Shi B. 2017. Molecular level understanding of the stability difference in collagen induced by chromium sulfate and aluminum sulfate. Journal of the Society of Leather Technologists and Chemists, 101, 273-279.

12. Wang L, Han WM, Yu Y, Zhou JF, Zhang WH, Shi B. 2017 Thermodynamic investigations on chrome and aluminum tanning. Journal of the American Leather Chemists Association, 112, 360366

13. Krawecki CZ. 1980. Methode non convetionnelle de tannage chrome/aluminium. Technicuir, 4, 73-76.

14. Dilek Y, Basaran B, Sancakli A, Bitlisli BO, Yorgancioglu A. Evaluation of collagen hydrolysate on the performance properties of different wet-white tanned leathers. Journal of the Society of Leather Technologists and Chemists, 103, 129-134.

15. Tang HR, Covington AD, Hancock RA. 2003. Use of DSC to detect the heterogeneity of hydrothermal stability in the polyphenol-treated collagen matrix. Journal of Agricultural and Food Chemistry, 51, 6652-6656.
16. Hui C, Zhi-Hua S. 2008. Changes in hydrothermal stability of collagen with several catechin-metal compounds: A DSC study. Journal of the Society of Leather Technologists and Chemists, 92, 93-95.

17. Wang YJ, Guo J, Chen H, Shan ZH. 2010. Influence of containing moisture on hydrothermal stability of modified collagen thermal characteristics analysis by DSC. Journal of Thermal Analysis and Calorimetry, 99, 295-300.

18. Urudzhev RS, Demirova AM, Gadzhieva AM. 2005. O mehanizme vlijanija dublenija na termostojkost' kollagena. KozhevennoObuvnaja Promyshlennost', 2, 47-48.

19. Li Y, Zhao WG, Pan JH. Deformable patterned fabric defect detection with fisher criterion-based deep learning. IEEE Transactions on Automation Science and Engineering, 14, 12561264.

20. GOST 15092-80. 1982. Interstate Standards, Leather for gloves and mittens. Specifications, Moscow, 12p.

21. TS EN ISO 2589. 2016. Leather - Physical and mechanical tests Determination of thickness. Turkish Standards Institution, Ankara, $11 \mathrm{p}$.

22. TS EN ISO 3376. 2012. Leather - Physical and mechanical tests Determination of tensile strength and percentage extension. Turkish Standards Institution, Ankara, 13p.

23. TS EN ISO 4045. 2018. Leather - Chemical tests - Determination of pH. Turkish Standards Institution, Ankara, 14p.

24. TS EN ISO 4684. 2006. Leather - Chemical tests - Determination of volatile matter. Turkish Standards Institution, Ankara, 14p.

25. TS EN ISO 5398-1. 2018. Leather - Chemical determination of chromic oxide content - Part 1: Quantification by titration. Turkish Standards Institution, Ankara, 18p.

26. TS EN ISO 4048. 2018. Leather - Chemical tests - Determination of matter soluble in dichloromethane and free fatty acid content. Turkish Standards Institution, Ankara, 22p.

27. 27. Danilkovich AG, Chursin VI. 2002. Praktikum po himii i tehnologii kozhi meha. Uchebn. Posobie Dlja Vuzov, Moskva: CNIIKP, $413 \mathrm{p}$

28. Venkatachalam PS. 1962. Lecture Notes on Leather. Central Research Institute, Madras, India.

29. Kontou E, Farasoglou P. 1998. Determination of the true stressstrain behaviour of polypropylene. Journal of Materials Science, 33, 147-153.

30. Case J, Chilver A, Ross CTF. 1999. Strength of materials and structures. Butterworth-Heinemann, 720p.

31. Roylance D. 2001. Stress-strain curves. Massachusetts Institute of Technology, Cambridge University Press.

32. Nalbat S, Onem E, Basaran B, Yorgancioglu A, Yilmaz O. Effect of finishing density on the physico-mechanical properties of leather. Journal of the Society of Leather Technologists and Chemists, 100, 84-89. 